\title{
KNOWLEDGE MANAGEMENT IN ISLAMIC HIGHER EDUCATION
}

\section{(A Case Study on Implementation of Knowledge Management Tools in UIN SGD Bandung)}

\section{Lilis Sulastri}

State Islamic University (UIN) Sunan Gunung Djati Bandung, Indonesia.

Jl. A. H. Nasution No 105 Bandung, West Java

Email : lilis.sulastri@uinsgd.ac.id

\section{Hayder Al Hadey Ahmad Mohammed}

Political Science and Strategic Faculty, Alzaeim Al-azhari University.

Ahmad Gasim Hospital Street. Bahri, Khartoun, Sudan

Email : Hyder.Alhadi@gmail.com

\begin{abstract}
The demand on the implementation of knowledge management is even greater at higher education institutions as an institution that intersect with many academic activities and the development of a scientific assessment as occurs in UIN Sunan Gunung Jati Bandung. This study tried to explore and analyze how UIN SGD Bandung run management practices and various activities in it, especially within the framework of the management of intellectual assets owned as an important step of applying the knowledge management. More specifically, this study used a qualitative approach with descriptive-holistic methods and case study analysis, have tried to analyze the use of knowledge management tools in UIN SGD Bandung. This study in its analysis found that there are many deficiencies essentially and conceptually in the implementation of knowledge management conducted by the management UIN SGD Bandung. Some knowledge management tools, such as technology infrastructure, collaboration tools, taxonomy, also has not been applied properly. However, the cycle of activities related to the conversion process of knowledge, such as socialization, externalization, combination, and internalization, has been done in UIN SGD Bandung.
\end{abstract}

Keywords: Knowledge, Management, Knowledge of Management Tools, Intellectual Assets, Technology Infrastructure, Organization.

\begin{abstract}
ABSTRAK
Tuntutan penerapan manajemen pengetabuan ini babkan semakin besar pada lembaga pendidikan tinggi sebagai lembaga yang banyak bersinggungan dengan kegiatan-kegiatan akademis dan pengembangan kajian keilmuan seperti yang terjadi di UIN Sunan Gunung Djati Bandung. Penelitian ini berusaha menyelami dan menganalisis bagaimana UIN SGD Bandung menjalankan praktik manajemen dan berbagai kegiatan di dalamnya, terutama dalam kerangka pengelolaan aset-aset intelektual yang dimilikinya sebagai langkah penting dari penerapan manajemen pengetabuan tersebut. Secara lebib khusus, penelitian ini yang menggunakan
\end{abstract}


pendekatan kualitatif dengan metode deskriptif-holistik serta analisis studi kasus ini berusaha menganalisis penggunaan perangkat pendukung praktik manajemen pengetabuan di UIN SGD Bandung. Penelitian ini dalam analisanya menemukan bahwa terdapat banyak kekurangan secara esensial maupun konseptual dalam praktik penerapan manajemen pengetahuan yang dilakukan oleh jajaran manajemen UIN SGD Bandung. Beberapa perangkat pendukung praktik manajemen pengetabuan, seperti infrastruktur teknologi, perangkat kolaborasi, taksonomi, juga belum diaplikasikan dengan baik. Meski demikian, siklus kegiatan yang berkaitan dengan proses konversi pengetahuan, seperti sosialisasi, eksternalisasi, kombinasi, dan internalisasi, sudah banyak dilakukan di UIN SGD Bandung.

Kata Kunci: Ilmu Pengetahuan, Manajemen, Perangkat Manajemen Pengetahuan, Aset-aset Intelektual, Infrastruktur Teknologi, Organisasi.

\section{INTRODUCTION}

Knowledge management itself is generally defined as a collaborative and integrative approaches in creating, retrieving, managing, accessing, and using various forms of intellectual assets (Dalkir, 2005. p.4). This approach is widely used by various organizations whether they are public or private, in order to maximize all its resources, which are no longer focusing on material resources alone. These efforts are generally based on the realization that the level of competition and businesses today increasingly fierce, therefore, each organization is required to be able to innovate, to be creative, in order to open up opportunities and develop its presence in the middle of the competition. Innovation and creativity will not come automatically. They are the results of the management of sustainable intellectual assets undertaken by the organization concerned. This also then tries to be formulated in the concept of knowledge management.

An organization that has implemented the concept of knowledge management in its management practices will not rely its performance on personal capabilities. Its creativity will not decrease even if abandoned by its employees. Innovation continues despite the loss of personnel with the ability above average. Knowledge management makes the intellectual capital of the organization well institutionalized and easily accessed at any time the organization's management needs. Knowledge management makes the work line in the management become more effective and efficient, because they can learn and make certain standards from previous employment data (Dalkir, 2005. p. 20).

The demands on the need for knowledge management is applicable to all types of organizations, not only companies with business orientation and profit, but also public organizations such as educational institutions. In the context of educational institutions, especially universities, these demands become greater because they are the locus of the development of science and 
scientific research (Mikulecka \& Mikulecky, 2000, p. 157-165). Universities are not only required to have institutional management that is more oriented to the management of all the modalities of its intellectual, but are also expected to give a good example in terms of the knowledge management for other organizations.

One of the state Islamic higher educational institutions which transformed into a university was the State Islamic University of Sunan Gunung Djati Bandung (formerly the State Islamic Institute of Sunan Gunung Djati Bandung). This transformation was originally expected to raise the quality of higher education and prove the readiness of the Islamic universities in facing the global demands. However, until the beginning of 2015, the rank of UIN Sunan Gunung Djati (UIN SGD) Bandung itself was still not able to get into the top 50 ranks of the best university in Indonesia. The data from 4ICU noted that the UIN SGD Bandung was at position 62, and Webometrics put UIN SGD Bandung in the $59^{\text {th }}$ rank. It represented the fact that UIN SGD Bandung had not been able to maximize the concept and implementation of knowledge management in the management of the institution in general as one of the big Islamic universities in Indonesia.

Based on the preliminary data obtained by the author, UIN SGD Bandung until the study was conducted, did not even have the information management system that was well integrated between one department to the others within the faculty, or between one faculty and the other faculties within the university, then up to the managers as the top management and the executors of learning and educational activities (departments/studyprograms) as line workers. Whereas the existence of information systems was an important element in the success of knowledge management practices in an organization. Some of the knowledge management, such as the findings of the knowledge deficiency, the improvement and purchasing of knowledge, the sharing of knowledge, as well as the evaluation of knowledge, also did not function properly (Dagli, 2009, p.1272). This was, for instance, shown by the lack of funding for research and other scientific activities at the department level. In some departments or study programs, the availability of funds was even almost nil from the rector (top management) so they had to find the funds by themselves to finance the research and student activities. Several other indicators could also be found related to the functionalization and application of the knowledge management tools.

Subsequently, these matters became the basis for the author's interest for further research regarding the concept of knowledge of management at the Islamic university, which would be specifically focused on the study of how the knowledge management tools were implemented at UIN Sunan Gunung Djati Bandung. 


\section{Problem Formulation}

Based on the background of the problem and the above phenomenon, the main issue discussed in this study is about knowledge management in Islamic universities, particularly how the knowledge management tools were implemented at UIN Sunan Gunung Djati Bandung. In more detail, the questions to be answered in this study are as follows:

1. How is the concept and practice of knowledge management at Islamic universities?

2. How is the implementation of knowledge management tools in Islamic universities, especially at UIN Sunan Gunung Djati Bandung?

3. What is the impact of the implementation of knowledge management tools to the existence of Islamic universities, especially UIN Sunan Gunung Djati Bandung?

\section{Data Collection and Analysis}

In this qualitative research, the data collection was done selectively; not all of the data was collected, but only the data relevant to the research that was collected in this study. As mentioned previously, the source of the data used as reference for this study include verbal sources, observational sources, and mediated sources. Thus, the data were collected through documentation, observation, and interview.

In addition, the practice of data analysis is closely related to the type and method of study chosen. In the context of this study, the activities of data processing and analysis were conducted by using a combination of qualitative analysis methods and case-study analysis methods.

\section{LITERATURE REVIEW}

\section{Definition of Knowledge Management}

Knowledge management has basically diverse definitions and none of them remains intact and is regarded as the standard definition of the knowledge management. In a simple example, knowledge management can be defined as the conversion of tacit knowledge into explicit knowledge and pass it on within the organization. If interpreted more technically, knowledge management is a process in which organizations attract and collect the values of its knowledge and intellect assets. Withdrawn from here alone, it becomes clear that knowledge management focuses on the identification, acquisition, distribution, and management of knowledge as things that are essential for the organization. The diverse definition of knowledge management can be seen from the perspective as shown in the following table: 
Table The Orientation of Definition of Knowledge Management

\begin{tabular}{|l|l|}
\hline \multicolumn{2}{|l|}{ What is Knowledge Management? } \\
\hline $\begin{array}{l}\text { Definition of results- } \\
\text { oriented }\end{array}$ & $\begin{array}{l}\text { Have the right knowledge at the time, place, } \\
\text { and the proper form as well. }\end{array}$ \\
\hline Process-oriented definition & $\begin{array}{l}\text { Management is a systematic process in which } \\
\text { knowledge is identified, created, collected, } \\
\text { disseminated, and applied. }\end{array}$ \\
\hline Technology Orientation & $\begin{array}{l}\text { Business intelligence + collaboration + } \\
\text { search engines + intellectual agents. }\end{array}$ \\
\hline
\end{tabular}

(Source: Uriarte Jr., 2008, p.13)

In the table above, it can be seen that the definition of the perspective knowledge management can be differentiated from the focused-orientation definition used. At the results-oriented definition, the knowledge management can be defined as how the organization has the knowledge, at the right time, the right conditions and environment, and the right form of knowledge as well. On the process-oriented definition of knowledge management, knowledge management is defined as the practical steps of an organization to identify, collect, share, disseminate, and apply this knowledge to achieve the defined objectives. While in the technology oriented definition, the knowledge management is formulated as a combination of business intelligence coupled with the collaboration among organizational elements, the activation of machines or devices of the organization in maximizing knowledge assets it has, as well as managing agents of intellectual for its long term interests.

Knowledge is basically one of the company's intangible assets. An organization can use these intangible assets as a device to determine its capabilities, external conditions and various changes and challenges it faces, and what steps should be taken to achieve the objectives that have been set forth. Liebowitz (1999, p. 34) in this regard states that the knowledge used in an organization is the result of interaction between two main components, namely human capital and information. Human capital is the thought and character of human competence determined by intelligence, imagination, intuition, education level, skills, experience, and other attributes of humanity. While information includes documentation of experiences and achievements or performance of the human intellect, as well as formulas that contain solutions to specific problems, or other information assets of the 
organization, such as performance reports, yearbooks, research, organization database, even certain patents that have been achieved.

\section{Types of Knowledge Management}

The knowledge possessed by a person or an organization, as described by Nonaka and Takeuchi $(1995$, p. 22), basically has two types, they are tacit knowledge and explicit knowledge. The Categories of tacit and explicit knowledge are obtained from Michael Polanyi, who explains that the difference between the two is important to understand how the management of knowledge in the broad interest. Tacit knowledge itself is defined by Groff and Jones $(2012$, p. 3) as the knowledge that refers to personal knowledge embedded in individual experience and involving intangible factors such as personal belief, perspective, and values. This definition implies that tacit knowledge is knowledge of individuals or knowledge owned by individuals and integrated with the experience and the other intangibel factors such as individual trust or beliefs, perspectives, and values that he/she believed.

While explicit knowledge is the knowledge that refers to tacit knowledge that has been documented. It has been articulated into formal language and can be much more easily transferred among individuals. This statement explains that explicit knowledge is tacit knowledge that is already documented. Explicit knowledge is knowledge that has been articulated into formal language and can be easily transferred to others through the process of learning and education. Similarly, Nonaka and Takeuchi (1995, p. 22) themselves explained that explicit knowledge (documented, computer) readily accessible, as well as documented into formal knowledge resources that are Often well organized. Explicit knowledge is knowledge that is readily accessible because it has been documented into formal sources of knowledge that are well defined. The sources of this knowledge can be documentation, archives, databases, and other matters related to knowledge that can be read, seen, and heard by every member of the organization or company.

The difference between tacit knowledge and explicit knowledge become important in understanding the objectives of knowledge management at the beginning. Starting from the difference in this types of knowledge, an organization is ultimately required to be able to access and manage tacit knowledge are diverse and owned by all members or human resources, to be used as a shared knowledge that can be accessed, shared, distributed, and used for the benefit of the organization, Therefore, making tacit knowledge become explicit knowledge is essentially a task and an important part of knowledge management.

Theoretically, the practice of knowledge conversion within an organization, as outlined by Nonaka and Konno (1998, p. 40-54) is 
originated from the practice of knowledge creation by individuals. The knowledge is then collected and standardized in a company so that it can become knowledge for others. In this model, there are four models of knowledge conversion commonly done in knowledge management, namely:

1. The conversion from tacit knowledge to tacit knowledge is called the socialization process. Socialization includes the tacit knowledge sharing between individuals. The term socialization is used as tacit knowledge is disseminated through the joint activities such as living together, spending time together and not through written or verbal instructions.

2. The conversion from tacit knowledge into explicit knowledge called externalization process. Externalization requires the presentation of tacit knowledge into a more general form that can be understood by others. At this externalization stage, an individual commits to a group and becomes one with the group.

3. The conversion from explicit knowledge into explicit knowledge is called the combination process. Combinations include the conversion from explicit knowledge into a more complex explicit knowledge.

4. The conversion of tacit knowledge into explicit knowledge is called the internalization process. Internalization of new knowledge is the conversion of explicit knowledge into tacit knowledge of the organization. Individuals must identify knowledge that is relevant to their needs in the knowledge of the organization.

The four points above are the models of knowledge conversion into a major focal point in knowledge management, as showed in the chart:

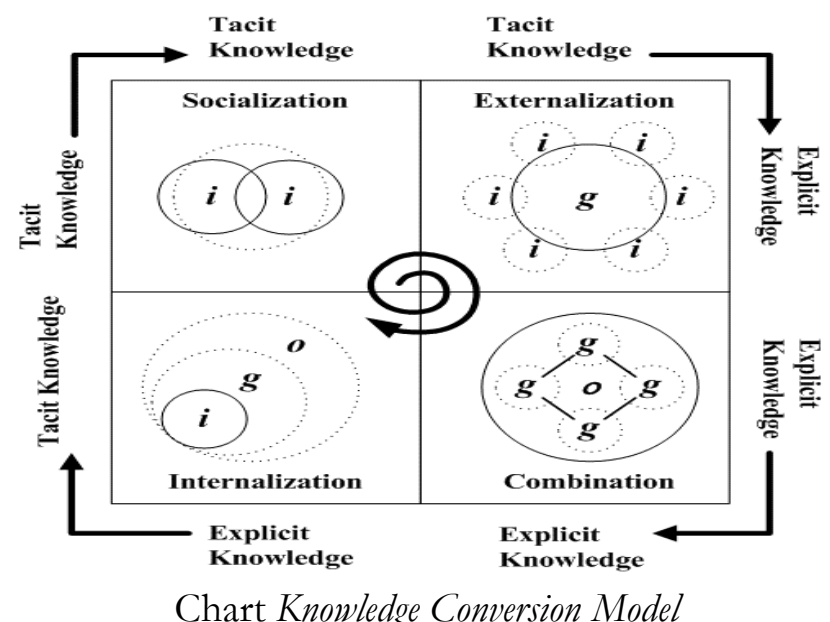


Based on this case as well, then as emphasized by Groff and Jones (2012, p. 2), that knowledge management is taken as tools, techniques and strategies to retain, analyze, organize, improve and share business expertise. Knowledge management should be seen as a device, technique, and strategy for storing, analyzing, organizing, enhancing and disseminating business experience or skills. The same thing is also expressed by Wiig in Larisa (2003, p. 127) that knowledge management is the systematic, explicit, and deliberate building, renewal and application of knowledge to maximize an enterprise's knowledge related effectiveness and return from its knowledge assets. Knowledge management is development, renewal, and application of knowledge to maximize the effectiveness of the company related to the knowledge then returning it into knowledge assets.

In more technical, Hibbard in Stehr \& Grundmann (2005, p. 287), states that knowledge management is process of capturing a company's collective expertise wherever it resides-in databases, on paper, or in people's head-and distributing it to wherever it can help produce the biggest payoff. Knowledge management is a process of acquiring the collective company's ability wherever it is, whether in a database, on paper, or in one's mind, then distributing them to any place where it can help produce or generate great profits for the company.

The definitions and the composition of knowledge above basically show that knowledge management is a systematic effort that must be undertaken by an organization to leverage knowledge assets it has, in any way, for the sake of the future of the organization. This knowledge is important to get and, at the same time, to preserve the ways and values of the best that can be obtained and disseminated by an organization or a company to achieve the expected goals. Without the knowledge management as one of the most valuable assets for the organization or company, there will be no innovation or achievement of certain values that can be used as guidelines.

\section{FINDINGS \& ANALYSIS}

\section{Concept and Practice of Knowledge Management in UIN Sunan Gunung Jati Bandung}

The implementation of knowledge management practices at UIN SGD Bandung was basically a practice that involved all elements of management as well as all elements of the institutional division from the largest to the smallest unit. Several research findings show that:

\section{a. Various Practices and Knwledge Management}

First, the various practices contained in the definition of knowledge management in general were largely carried out by the various implementing elements of the activities and management policies at UIN SGD, especially 
in this case the lecturers or faculty and students. These practices included the knowledge identification, the creation and acquisition of knowledge, the distribution and dissemination of knowledge, as well as the implementation of knowledge at various required levels.

In the implementation of knowledge management involving the knowledge identification process, what was done by the management of UIN SGD was running taxonomy or the mapping of the intellectual assets and the individual skill or expertise of the employees and lecturers. Although the taxonomy was already done, it runs without a structured action involving certain division for the mapping. The management was more likely to passively listen to the aspirations of the bottom about the development of individual values recorded on the academic activities. It is of course in the different direction to what was expected by the management of knowledge itself; that the management should be actively involved in tracking intellectual assets owned by the institution, especially those recorded in the form of tacit knowledge of the faculty, staffs, or students. Taxonomies or knowledge mapping process itself would only be valuable if it was recorded systematically, and got a follow-up note. This taxonomy note should be a basis for the management to set position, or responsibility to be carried by the individual concerned in the management activities or practices of teaching and education held by UIN SGD Bandung.

The next process, i.e. the creation and acquisition of knowledge which was an integral part of knowledge management applied in UIN SGD Bandung relied more on the academic activities that became the locus activities of higher education institutions like the UIN SGD itself. The management of UIN SGD Bandung seemed to only rely on the willingness of certain individuals to seek knowledge in accordance with the interests and needs, or rely on the activities of scholar studies such as panel discussions, lectures, training and personal development which were done personally, or studies that had not been systematically facilitated as part of the management planning of UIN SGD Bandung itself. Supposedly, the management of UIN SGD Bandung could be more capable of participating in the creation and acquisition of knowledge, particularly by providing the means or formulating policies that facilitated skills development programs, research, and other scientific activities.

At the next practice, the distribution and dissemination of knowledge, the management of UIN SGD Bandung also relied more on teaching and learning practices or lectures as means of distribution and dissemination of knowledge. Though, the practice had become part and the main task of an educational institution like UIN SGD Bandung. What the management UIN SGD Bandung should do in this case to provide distributive devices for the 
dissemination of knowledge equally to all elements of the institution, not just the teachers and the students, but also all the employees and the labor involved in organizing the educational activities or general management activities.

While the implementation or the embodiment of knowledge made by the management of UIN SGD Bandung in this case was done by relying on the classic activities, such as students' job training (PKL or CCN), or the application of new scientific findings in lecture practices whereas the implementation of knowledge in the knowledge management was more than that. The desired result from the practical implementation of this knowledge was that the UIN SGD Bandung management ought have been be able to accommodate a wide range of its intellectual assets into the base or foundation of the implementation of the overall management activities.

\section{b. Techniques and Strategies of Knowledge Management Implementation}

Second, the techniques and strategies for the implementation of knowledge management conducted at UIN SGD Bandung, basically had run mainly by practicing the patterns of the classic strategy of learning, applying general techniques and strategy of the explicit management knowledge by way of documentation the reviews and learning materials or lectures and material enrichment of institutional governance, as well as classic techniques and strategies related to the management of tacit knowledge, especially with enriched skills and expertise of the lecturers through the programs of quality development and personal training.

The efforts done by the management of UIN SGD Bandung related to the selection and application of techniques and strategies for the implementation of knowledge management dwelled more on the classic strategy in the form of training and formulation of programs in the development of skill and quality of the lecturers or employees, were also not scheduled systematically and periodically. Yet what should be done by the management UIN SGD Bandung related to sorting and application of techniques and knowledge management strategy was to carry out some techniques and strategy of knowledge management that theoretically grew rapidly in the study of contemporary management. Some forms of techniques and strategies, for example, was adapted to the main elements of knowledge management such as the use brainstorming techniques for the taxonomic purposes and knowledge mapping, technology engineering for the purposes of the conversion of tacit knowledge into explicit knowledge, and so on. 


\section{c. Conversion of Tacit Knowledge into Explicit Knowledge}

Third, the process of converting tacit knowledge into explicit knowledge as one of the important steps of knowledge management, to some extent, was also already applied in the classic formula in UIN SGD Bandung.

The practice of knowledge conversion, either from tacit knowledge into explicit knowledge, or from tacit knowledge into tacit knowledge again, or explicit knowledge into tacit knowledge or explicit knowledge into the next explicit knowledge was the main agenda of knowledge management in a variety of forms of organizations, including the higher education institutions as UIN SGD Bandung. Classic pattern of conversion in the form of teaching, training, or research, became an integral part of management and education practices in UIN SGD Bandung. However, relying on it alone would not make the practice of conversion run as desired from the knowledge management itself.

According to the theoretical conception of practical conversion knowledge above, then what should be done by the management UIN SGD Bandung in this regard was the intensification of the process of socialization, externalization, combination, and internalization of knowledge that all forms of knowledge conversion above could be run properly. The socialization process as the conversion from tacit knowledge into the next tacit knowledge, or the spread of expertise from one individual to another could be done by the management of UIN SGD by establishing teamwork or working groups, or giving certain instructions that require employees or faculty to cooperate and being connected each other, resulting in the exchange of information and insight that was more intense and personal between members of the working group.

\section{d. Various Tools of Knowledge Management}

Fourth, the use of various tools of knowledge management, such as document management, organization or institution portals, knowledge mapping and skill management, information database and the materials being studied, collaboration tools, and practical community, was already underway, although in a certain scale of the mandatory use, the management of UIN SGD Bandung could not fully achieve it.

The findings on the implementation of knowledge management at UIN SGD Bandung above shows that the implementation of knowledge management in UIN SGD Bandung did not have clear implementation concept and was supported by facilities and infrastructure needed in its implementation. Whereas the implementation of knowledge management required clear concept that understood by all boards of the management of 
UIN SGD Bandung. In addition, knowledge management should also be carried out taking into account the availability of the main supporting pillars, namely: (1) management and organization; (2) infrastructure; (3) people and culture; and (4) the content management system. The four pillars were things that made the implementation of knowledge management within an organization become possible.

\section{The Implementation of Knowledge Management Tools in UIN Sunan Gunung Jati Bandung}

The implementation of knowledge management at UIN SGD Bandung, as described previously was carried out despite the modest levels and more dependent on the classical process of knowledge management as commonly found in educational institutions. The existence of teaching and learning activities or lectures, a culture of research and scientific discussions, as well as the human resources in the academic form, made activities at the heart of the practice of knowledge management able to run from the outset, although not structured in the agenda systematically as a planning professional management.

The acquisition of knowledge, for instance, could be easily done through the practice of lecturing or learning, forums of scientific study and knowledge discussion, or training programs and personal development which were mostly done on campus or institution of higher education in general as in UIN SGD Bandung. Similarly, the practice of knowledge distribution could easily be seen in the process of information and knowledge exchange, in lectures, seminars, workshops, regular review, publication of research results and scientific papers, as well as a variety of scholar activity that involved the elements of lecturers and students as well as the management of UIN SGD Bandung itself. While the use of knowledge or the implementation of the results of the study could be found practically in forms of community service that was run by a faculty member or a student, or in other forms of cooperation established between UIN SGD with other institutions, including in this case the firms labor receiving graduate UIN SGD Bandung.

However, the process, as parsed in the previous section, was not enough without concrete and renewable steps based on the development of the study of management practices of the contemporary knowledge, especially with regard to the use of implementation techniques and strategies or formalization agenda with regard to the more systematic knowledge conversion.

Furthermore, the application of knowledge management itself needed some major device, which also became the research interview materials with 
multiple sources of research to determine the extent of the seriousness of the management board in UIN SGD in implementing the knowledge management programs in the institution. The results and findings of these interviews show that:

The first, related to document management that was run by the management of UIN SGD, then the management of UIN SGD Bandung in this case appointed the personnel who were selected through a specific recruitment method as bureaucratic rules and institutional authority that was connected to the central government. In this context, institutional management was more directed as the main administrative functions of the division of administration, as well as the supporting administrative functions for the other divisions.

The first use of knowledge management tools, namely document management in UIN SGD Bandung, was basically run as appropriate governance and archives administration office in modern organizations. Management board of UIN SGD even went further by doing the design recording instruction, implementation, and results of various activities, whether were included in academic activities such as lecturing, research, and field practice, or institutional events such as documentation of functional activities, seminars, proceedings, gatherings, consortium meetings, and so on. Notes and recordings were then stored or documented either through reports, writings, images, videos, manual instruction, or in the form of files in a database of information on technological devices contained in certain faculty or study program and divisions of the management at UIN SGD Bandung.

However, document management conducted by UIN SGD management was not evenly distributed in every line of work, especially at the level of a study program as a unit that more frequently dealt with learning activities and other academic matters. Indeed, the document management must have been well-managed, effective, systematic, and beneficial, not only for the management of the access to data or information that is necessary, but also for professors, students, in the context of academic services and improving the quality of education held.

Secondly, UIN SGD Bandung later had information portal that could be accessed by the public through a dedicated website, which www.uinsgd.ac.id. This site served not only as a provider of information about the educational institutions and the various services it offered, but also as a communicative medium to disseminate various forms of knowledge and scientific research to the general public as stakeholders of higher education.

At UIN SGD Bandung, its website already had a good interface level, although its visibility has not reached the level that it should. This is seen 
from a comparison of the information provided in the website UIN SGD Bandung with other universities which entered the ranks of the best universities according to Webometrics. Some links provided in the website were also not fully accessible, even at times where there was high visitor traffic, the website of UIN SGD could not be accessed properly. This indicates that the level of security UIN SGD website was not maximized as commonly as the official website of government and global business enterprises.

Third, related to the efforts done by management of UIN SGD Bandung in mapping intellectual assets and, in particular, the tacit knowledge possessed by its members, the management UIN SGD Bandung in this regard had done the identification persuasively towards the personnel, both from the teaching staff (lecturers), the employees, to students who were considered to have the expertise and skill or mastery of a particular scientific field. Those who were identified as having expertise or mastery would be recorded for later within the context of scientific activities, and given the task and the confidence to develop their expertise in the form of creating a scientific paper, the source person of panel discussions, or were given teaching materials or lectures in accordance with the field expertise of each personnel.

As far as the researcher had found, what was done by the management of related UIN SGD Bandung taxonomy is the mapping and recording of intellectual assets and expertise personnel based solely on the visibility of the individual who looked through the works of the individuals. In fact, the mapping of the intellectual assets and the tacit knowledge contained in individual members of the organization must be either through, for example, data collection and record-keeping on the development of capabilities in a systematic and ongoing faculty. Therefore, the management of UIN SGD had to integrate the steps of the implementation of this knowledge management throughout the planning and implementation of activities undertaken by all lines of work.

Fourth, the management UIN SGD Bandung built the information and communication technology facilities in every locality division connected with other divisions. At the faculty unit, the management of UIN SGD also built a network of computer technology that connected between the department or study program and the Department or other study program in the Faculty in allied science. Intranet, although had not yet been functioned optimally as a tool of communication and interaction or database information, especially because often hit technical problems in practice, it already showed a good effort from the management of UIN SGD Bandung to build linkages between a division with others, between one work unit with 
the other work units, as well as between the top management with the executing underneath. However, the technology infrastructure in UIN SGD Bandung must be supported by training in the operational expertise development among employees and lecturers.

Fifth, related collaboration tools as one of the important tools of practical application of knowledge management, the management of UIN SGD Bandung in this case has made some efforts to establish work units that combine several skilled personnel and new energy to solve a problem, or the extent of training needs cooperation between elements of existing institutions.

Collaboration tools in the context of the implementation of knowledge management in UIN SGD Bandung basically could be represented through the formation of teamwork or working groups, mentoring, professors' forums, student activity units, and the cooperative employees. What was done by the management of UIN SGD led to the success, by establishing a culture of consultation and cooperation between elements of the institution, both from the management or executive activities. The note taken for the process related to the implementation of knowledge management is that the management of UIN SGD formed working groups or gave instructions to some of the personnel for the execution of certain tasks, which were not geared to all of the interests of the collaboration intellectual assets.

Collaboration tools could also be implemented through the creation of interactive communities with other parties outside the organization. The board UIN SGD management, for instance, may establish cooperation with companies or similar educational institutions to exchange information and means of knowledge implementation, such as that was done by other leading universities.

Sixth, related to the location existing activities, UIN SGD Bandung in this case was centered on the location of activities, the campus located at Jl. AH. Nasution No. 105, Cipadung, Cibiru. However, several other campuses were affiliated with UIN SGD Bandung as educational institutions that are considered to be the center of enrichment and supporting lecturer at various remote locations to the main campus. In this context, UIN SGD yet had the means in the form of interactive virtual device that connects between the central management of UIN SGD Bandung and the public as stakeholders in the area of education, or the personnel who accidentally deployed in the framework of community service performed by UIN SGD Bandung. Therefore, it is possible the location of the existing campus must now experiencing growth and expansion, which means requiring a new location, especially to accommodate the needs of people in the region would be higher 
education based on Islam but also can produce graduates who are ready to work and compete globally as the meaning of UIN SGD vision itself.

\section{Impacts of the Implementation of Knowledge Management Tool Against the Existence of UIN Sunan Gunung Jati Bandung}

This issue became one of the biggest challenges to be faced by the management of UIN SGD Bandung in the implementation of knowledge management in the institution. They are required to not only find and manage intellectual assets owned, before that they are required to change the work culture, ideas and viewpoints of the intellect, as well as the environment and the way the organization treats the members or employees. Therefore, the management of UIN SGD must be able to instill the awareness that intellectual assets in the form of expertise, skills, capabilities, contained in a person, would never diminish when it shared or distributed. Instead, the skills that will be more refined when the skills learned through training and spread evenly on everyone. Those who have the expertise and skills will be even more motivated to improve their capabilities in an environment where everyone is encouraged to further improve the quality themselves through learning.

Based on this case as well, the implementation of knowledge management could be done, when every person involved in the management of motion in UIN SGD institutions realized that the progress and success was difficult to achieve if there are only a few of them who have the capabilities needed to achieve that success.

The implementation of knowledge management in UIN SGD Bandung, in practice, was run more by relying and resting on academic activity that has become the main task of the higher education institutions themselves. Nevertheless several stages and cycles of knowledge management activities such as identification, documentation, conversion, and implementation has been a lot of running on the management practices in UIN SGD Bandung.

In addition, it should be noted that there are three things that will affect the implementation of knowledge management, the human resources and organizational culture aspects, regulatory aspects, and aspects of funding. Reflecting the findings of the study, what was done by the management UIN SGD Bandung related to the implementation of knowledge management, then leads to some critical notes related to these aspects.

The first aspect is the human resources of the organization. As previously described, the management of UIN SGD Bandung should have not lack of the human resources or the formulator for implementing the knowledge management programs, because it is inhabited by academics with 
high level scientific and intellectual. If there is to be done by the management of UIN SGD, that is only the spread and intensification of the programs expected to be implemented within the framework of the implementation of knowledge management so that it gained the support of all elements and personnel agencies from the organization itself, both the employees, the lecturers, and the students.

The second is the organizational culture. In the previous section also mentioned that the management of UIN SGD Bandung does not need to build a culture of appreciation for the intellect and knowledge as well as other organizations. This is due to educational institutions has made the award will be the values of intellect and knowledge as the core values underlying in the various on-going activities. The culture built from the outset on the campus UIN SGD is the academic culture, which means it supports the implementation of knowledge management itself. If any, the only thing to worry about by the management UIN SGD in the context of the organization's culture is the mentality of bureaucracy and staffing problems that often make the civil servants, like the lecturers and staffs, to innovate in the absence of more demand as organizations or private educational institutions. In addition, political and cultural power struggles should be avoided and kept away from academic culture. What often happens in Islam-based higher education institutions, like the UIN SGD Bandung, is a battle between the camps and communities (eg HMI vs PMII) in the name of ideologies and interests that actually leans on the demands of an academic.

The third is the regulatory aspects. At state higher education institutions such as the UIN SGD Bandung, it does not have full freedom to run their own rules and policies. There is regulation of government and bureaucratic hierarchy that makes the management of UIN SGD must obey the instructions of the institution on it. It is on one hand can make the implementation of knowledge management hiccup, especially if the management of UIN SGD is unable to accommodate the policies and rules of the center within the framework of the implementation of knowledge management is needed by the institution. In addition, to facilitate the implementation of knowledge management, the management of high-UIN SGD Bandung also should prepare a regulatory umbrella for the entire knowledge management program that will be disseminated and followed by all elements of the institution UIN SGD Bandung. Without regulatory aspects in the form of binding rules, the knowledge management programs difficult to run effectively.

The fourth one is the funding aspect. Commitment of the top board management of UIN SGD is absolutely necessary for the implementation of 
knowledge management. This commitment must be followed up with real applications in the form of policies and the provision of material and financial resources for all the activities required within the framework of the implementation of knowledge management. Program at no cost is hard to run. Hence, if at this time, as shown in the research findings, UIN SGD Bandung do not yet have the facilities and infrastructure required for the implementation of knowledge management in an effective and thorough, then the management commitment UIN SGD deserves to be questioned.

In addition, more technically, there are some things that should also be considered the management UIN SGD Bandung, related to the implementation of knowledge management, namely:

1) Habit formation

One effort that can be done to prepare human resources and build a climate that is conducive to building a habit to share data and knowledge. This habit will require also the habit of using accurate data and store the data held neatly. Basic requirements in the formation of this habit are by setting the position of the data as belonging to the organization. In this activity might still exist conflicts of authority, collision regulations and the question of the accuracy of the data. This can be resolved by agreement among the units of work involved.

2) Provision of Advocacy

Governance will not be effective if the Advocacy does not have sufficient or even collide with the existing formal rules. The formulation of the governance of knowledge in a knowledge management strategy is followed by the establishment of a regulatory framework to support. For example, the successful implementation of knowledge management in one of the leading State Owned Enterprises (SOEs) in a telecommunications is a regulations governing corporate knowledge governance in addition to their corporate strategic planning that supports knowledge management strategy.

3) Utilization Technology

With the increasingly large volumes of data and complex data requirements, it is almost impossible to manage knowledge in organization manually. The role of information technology will be very dominant in this case and will at least include the following requirements:

a) Acquisition and processing of data

This process include a system for recording electronic data, both structured data (database) and unstructured (in the form of 
description text, images, video, audio, etc.), a system for data processing (including preparing an index, catalog, and etc.), and the classification of knowledge

b) Dissemination of knowledge

- Facilities for the dissemination of information as well as communication and collaboration, such as Internet and Intranet portal technology, electronic discussion forums, system electronic catalog, as well as the system of search and retrieval (retrieval) of information - both systems manual search or an early detection system would need data and information;

- The system ruling the right of access to use their knowledge and keep it confidential.

c) evaluation, development and improvement of knowledge

In the early stages can include an electronic discussion forum and knowledge catalog systems. In the long term, if it has done the integration of information systems that are used in the work process within the organization, this facility can be developed to detect the utilization of the existing knowledge in decisionmaking in all lines of the organization.

4) Alignment of Knowledge Management Strategy with Strategy Change Management The implementation of knowledge management is also related to the transformation of work culture in the organization. Therefore, the continuous alignment with change management strategy needs to be done. Each dynamic that occurs will be very potential to affect each other both. Output in the phase of Implementation of Knowledge Management include, among others:

a) Implementation of the strategy and work plan knowledge management;

b) Development of legal framework to support the implementation of knowledge management on an ongoing basis;

c) Report ofthe development progress of the implementation of knowledge management and synchronization with the change management implementation.

If all of the above matters related to the implementation of knowledge management, especially the use of devices supporting the implementation of knowledge management, especially in agencies UIN SGD runs well, then the implementation of knowledge management would work well too. The success of the implementation of knowledge management will bring 
significant changes to the management of productivity and performance of the institution itself thoroughly.

Based on interviews at random on some elements of the institution in UIN SGD Bandung, the researcher, for instance, got answers regarding the impact of the application of the knowledge management tools, namely:

First, the implementation of management policies related to the implementation of knowledge management programs, such as programs for the conversion of knowledge in its various forms (socialization, externalization, combination, and internalization), intensification of activities related to mapping intellectual assets, scientific studies and research, development of personnel skills, and members of the institution, to the development of institutional infrastructure and better education, have a significant impact on the change in behavior management and employees as well as their views on the institution itself UIN SGD. Campus construction and the provision of better infrastructure-related learning tools, technology, communications, and others have brought a new working environment for line management to make them more excited and motivated to work better in accordance with the conditions of the new campus. The existence of policies and instructions upper management to do things that are part of the implementation of knowledge management, such as the establishment of teamwork, assignment based on expertise, procurement training programs, is also a little more to make employees and management team over have the necessary competence for the benefit of development UIN SGD Bandung in the future.

Second, the implementation of knowledge management practices, though has not yet thoroughly and clearly disseminated to all elements of the organization, especially the teachers and students, but the programs are launched have brought benefits to the development of academic activities in UIN SGD itself. Intensification of research programs for professors, for example, makes the faculty more motivated to improve the quality of its science and expertise in order to play an active role in the program. The same thing can also be found in management's efforts to build infrastructure related to the implementation of knowledge management, such as the provision of academic programs that enhance the scientific spirit and appreciation for knowledge and intellect, or on how the management effort UIN SGD Bandung in the provision and improvement learning infrastructure and education as well as a database for information services for faculty and students.

The use a variety of tools supporting the implementation of knowledge management, such as document management, information portals, technology infrastructure, taxonomy, as well as collaboration tools, all other 
words have brought a positive impact for the management, employees, teachers, to students in UIN SGD Bandung. What needs to be done by the management UIN SGD Bandung after seeing it merely seeks more seriously and better in implementing knowledge management in accordance with the conception and theory are well adapted to the needs and contour the body UIN SGD Bandung.

\section{CONCLUSION}

Research on knowledge management, which focused on the study of the knowledge management at the State Islamic University of Sunan Gunung DJati (UIN SGD) Bandung, in its analysis resulted in the following conclusions:

Knowledge management practices contained in UIN SGD Bandung still do not have a clear conception and implementation of standardized and systematic format. What is done by the management UIN SGD Bandung related to this knowledge management practices rely more academic activities that had become the locus of activities of higher education institutions themselves. Some elements and aspects required for the implementation of knowledge management, such as management commitment, organizational culture, human resources, information technology and communications infrastructure, to regulations and policies are already widely available and are run by management UIN SGD Bandung. However, it has not been patterned and formulated into an integral agenda of institutional overall management plan. This makes the practices required in the implementation of knowledge management as the identification, creation and acquisition of knowledge, distribution and dissemination of knowledge, implementation and use of knowledge, as well as the conversion of knowledge, either tacit or explicit difficult to grow and get maximum results.

A variety of devices supporting the implementation of knowledge management in an organization or institution, such as in UIN SGD Bandung, namely: document management, information portals institution or organization, technology infrastructure, mapping intellectual assets and knowledge or taxonomy, collaboration tools, and a community of practice , has not been provided and used optimally in tune with the needs of programs the implementation of knowledge management itself. Document management more done as an administrative governance has no purpose and is connected to the context of knowledge management, a lack of informative content in the portal institutions, inadequate insfrastuktur necessary technology, taxonomy more done based on the visibility of individual expertise, to the lack of device- collaboration tools become critical notes on 
the use of various tools supporting knowledge management in the UIN SGD Bandung.

Despite the various shortcomings, the use of various tools supporting knowledge management, as well as the implementation of knowledge management practices in UIN SGD Bandung itself, generally has a positive impact on the management, employees, faculty or lecturers, and students , The impact is represented by a change in their view would award on intellect and knowledge, morale is awakened, and the development of skills and abilities better.

\section{BIBLIOGRAPHY}

\& Konno, N., (1998). "The Concept of Ba: "Building a Foundation for Knowledge Creation," dalam California Management Review, 40-3, 1998. ., (2003). Manajemen, Dasar, Pengertian, dan Masalah. Edisi Revisi Jakarta: PT. Bumi Aksara. , (2008). Sumber Daya Manusia Stratejik. Bandung: La Good's Publishing.

Anand, Apurva \& Singh M.D., (2011). "Undertanding Knowledge Management: A Literature Review," dalam International Journal of Engineering Science and Technology (IJEST), (Uttar Pradesh, India, Vol. 3. No. 2., Februari 2011).

Berg, Bruce L., (2001). Qualitative Research Methods for The Social Sciences, $4^{\text {th }}$ Edition, (New York: Allyn \& Bacon, A Pearson Education Company, 2001).

Bhattacherjee, Anol., (2012). Social Science Research: Principles, Methods, and Practices. Florida: Scholar Commons University of South Florida, USF Tampa Library Open Access Collection.

Blundel, Richard., (2007). "Critical Realism: A Suitable Vebicle for Entrepreneurship Research?" dalam Helle Neergaard \& John Parm Ulhoi (ed), Handbook of Qualitative Research Methods in Entrepreneurship. London: Edward Elgar Publishing.

Bukowitz, Wendi \& Williams, Ruth L., (1999). The Knowledge Management Fieldbook. New Jersey: FT Press.

Cohen, Louis, et. al., (2000). Research Methods in Education, $5^{\text {th }}$ Edition, London: Routledge Falmer. Creswell, John W. 2007. Qualitative Inquiry \& Research Design, Choosing Among Five Approaches. London: Sage Publishing, 2007.

Dagli, Gökmen, et. al., (2009). "A Qualitative Research on the University Administrators' Capacity to Use Management Knowledge Tools (The Case of TRNC Universities)," dalam Educational Sciences: Theory \& Practice. Istanbul, Edam. 
Dalkir Kimiz., (2005). Knowledge Management in Theory and Practice. UK: Elsevier Inc.Douglas, Hall T. \& James, Goodale G. 1986. Human Resources Management, Strategy, Design and Impelementation. Glenview: Scott Foresman and Company.

Faustino, Cardoso Gomes., (2003). Manajemen Sumber Daya Manusia, Yogyakarta: Penerbit Andi.

Flick, Uwe., (2009). An Introduction to Qualitative Research, $4^{\text {th }}$ Edition. London: Sage Publishing.

Flippo, Edwin B. Manajemen Personalia, Edisi 6. Jakarta: Penerbit Erlangga.

Frensidy, Budi., (2007). "Persaingan Perguruan Tingi Indonesia: A Lossers' Game," dalam Usabawan No. 08, XXXVI Agustus.

Groff, Todd \& Jones, Thomas., (2012). Introduction to Knowledge Management, London: Routledge.

http://forlap.dikti.go.id/perguruantinggi/homegraphpt

http://id.wikipedia.org/wiki/Daftar_perguruan_tinggi_Islam_negeri_di_Ind onesia

http://www.4icu.org/id/

http://www.ditpertais.net/ptais01.htm

http://www.webometrics.info/en/Asia/Indonesia\%20

Kementrian Pendayagunaan Aparatur Negara dan Reformasi Birokrasi., (2011). Buku 8, Pedoman Pelaksanaan Program Manajemen Pengetahuan, Peraturan Menteri Negara Pendayagunaan Aparatur Negara dan Reformasi Birokrasi Nomor 14 Tabun 2011, Jakarta: Kementrian Pendayagunaan Aparatur Negara dan Reformasi Birokrasi.

Liebowitz, Jay., (1999). Knowledge Management Handbook. Florida: CRC Press.

Mikulecka, J. \& Mikulecky, P., (2000). "University Knowledge Management, Issues and Prospects" dalam Djamel A. Zighed, Jan Komoroswki, Jan Zykow, Principles of Data Mining and Knowledge Discovery 4th European Conference Proceedings. Lyon, France: Springer-Verlag Publisher.

Nonaka, I. \& Takeuchi, H., (1995). The Knowledge-Creating Company.New York: Oxford University Press.

Rivai, Veithzal., (2005). Manajemen Sumber Daya Manusia untuk Perusabaan dari Teori ke Praktik. Jakarta: PT Raja Grafindo Persada.

S. P, Malayu Hasibuan., (2000). Manajemen Sumber Daya Manusia. Jakarta: PT. Bumi Aksara.

Shavinina, Larisa V., (2003). The International Handbook on Innovation, Amsterdam: Elsevier.Simamora, Henry. 2004. Manajemen Sumber Daya Manusia. Yogyakarta: Andi Offset.

Snape, Dawn \& Spencer, Liz., (2003). "The Foundations of Qualitative Research", dalam Jane Ritchie \& Jane Lewis (ed), Qualitative Research Practice, A Guide for Social Science Students and Researchers. London: Sage Publishing. 
Stehr, Nico \& Grundmann, Reiner., (2005). Knowledge: Critical Concepts, Vol. 3. UK: Taylor \& Francis.

Sulastri, Lilis., (2009). Pengantar Manajemen. Bandung: LaGood's Publishing.

Uriarte Jr., Filemon A., (2008). Introduction to Knowledge Management. Jakarta: ASEAN Foundation.

Walliman, Nicholas., (2011). Research Methods, The Basics. New York: Routledge. 